\title{
Interrelations Between Glucose-Induced Insulin Response, Metabolic Indicators, and Time of First Ovulation in High-Yielding Dairy Cows
}

\author{
P. Bossaert, ${ }^{* 1}$ J. L. M. R. Leroy, † S. De Vliegher, ${ }^{*}$ and G. Opsomer* \\ *Department of Reproduction, Obstetrics and Herd Health, Faculty of Veterinary Medicine, Ghent University, Merelbeke B-9820, Belgium \\ †Laboratory for Veterinary Physiology, Department of Veterinary Sciences, Faculty of Pharmaceutical, Biomedical and Veterinary Sciences, \\ University of Antwerp, Wilrijk B-2610, Belgium
}

\section{ABSTRACT}

High-yielding dairy cows are more susceptible to metabolic and reproductive disorders than low-yielding cows. Insulin plays a pivotal role in the development of both problems. In the present study, we aimed to assess the glucose-induced insulin responses of dairy cows at different time points relative to calving and to relate this to the metabolic status and the time of first ovulation. Twenty-three healthy, multiparous HolsteinFriesian cows with a high genetic merit for milk yield were studied from $14 \mathrm{~d}$ prepartum to $42 \mathrm{~d}$ postpartum. Intravenous glucose tolerance tests were performed on $-14,14$, and $42 \mathrm{~d}$ relative to calving to evaluate the plasma insulin and glucose responses to a glucose load, as estimated by the peak concentration, the area under the curve (AUC), and the clearance rates of insulin and glucose. Blood samples were obtained at 3-d intervals and analyzed for glucose, insulin, and nonesterified fatty acids (NEFA). The time of first ovulation was defined by transrectal ultrasonography and plasma progesterone analysis. Glucose-induced insulin AUC and peak concentration decreased and glucose clearance increased during lactation compared with the dry period. Plasma NEFA concentrations were negatively related to insulin AUC and peak concentrations. Fourteen cows ovulated within $42 \mathrm{~d}$ postpartum, and the remaining 9 cows suffered from delayed resumption of ovarian function. Survival analysis demonstrated that cows with lower NEFA concentrations during the dry period tended to have earlier resumption of ovarian activity. In conclusion, our data suggest a decreased plasma insulin response to glucose postpartum in highyielding dairy cows, possibly contributing to metabolic stress during the early postpartum period. It is hypothesized that NEFA impair glucose-induced insulin secretion in dairy cows. Additionally, our results suggest

Received January 4, 2008.

Accepted May 28, 2008.

${ }^{1}$ Corresponding author: Philippe.Bossaert@ugent.be the importance of lipolysis during the transition period as a risk factor for delayed ovulation.

Key words: dairy cow, intravenous glucose tolerance test, insulin, first ovulation

\section{INTRODUCTION}

Average milk production in dairy cows has increased dramatically over the past decades. Unfortunately, an increase of the incidence of metabolic and reproductive disorders (Opsomer et al., 2000; Lucy, 2001) has been reported in high-yielding dairy cows, causing considerable economic losses (Shrestha et al., 2004b). This worrying trend is challenging scientists worldwide to shed more light on the inverse correlation between yield and fertility.

A large retrospective study has pointed out that $49 \%$ of Flemish high-yielding dairy cows suffer from ovarian dysfunctions postpartum (pp; Opsomer et al., 2000), resulting in lower conception rates and longer calving intervals (Shrestha et al., 2004b; Walsh et al., 2007). A delay of the first ovulation (DFO; no progesterone increase before $50 \mathrm{~d} \mathrm{pp}$ ), caused by inactive ovaries or cystic ovarian disease (COD) and a prolonged luteal cycle (ovulation followed by a progesterone increase for $>20 \mathrm{~d}$ ) were by far the most important causes of ovarian dysfunction. Although a prolonged luteal cycle seemed to be mainly related with dystocia and uterine disorders, clinical features indicative for a severe negative energy balance (NEB), such as clinical ketosis, severe body condition loss, and diseases affecting dry matter intake, were identified as major risk factors for DFO (Opsomer et al., 2000). Similar results were found by others (Shrestha et al., 2004a; Walsh et al., 2007).

The effect of NEB on fertility has been studied in more detail at our department. Interestingly, low plasma insulin concentrations appear to be associated in vivo with developmental disturbances of the follicle such as COD (Vanholder et al., 2005). This is in agreement with in vivo and in vitro evidence found by other authors. For instance, administering insulinogenic diets results in an earlier resumption of ovarian func- 
tion (Miyoshi et al., 2001; Gong et al., 2002). In vitro research has pointed out that insulin and insulin-like growth factor are major regulators of granulosa cell proliferation and estrogen synthesis (Spicer and Echternkamp, 1995; Gutierrez et al., 1997). Additionally, low insulin results in lipolysis and elevated peripheral concentrations of NEFA, which, in turn, have a detrimental effect on granulosa cell function (Vanholder et al., 2005) and increase the risk of production diseases such as ketosis, abomasal dislocation, and hepatolipidosis (Roche, 2006). Altogether, these data demonstrate that low insulin concentrations play a pivotal role in the development of reproductive and metabolic disorders. On the other hand, low insulin levels are associated genotypically (Gutierrez et al., 2006) and phenotypically (Ingvartsen and Friggens, 2005) with high milk yield. Although insulin has no direct effects on galactopoiesis, low insulin decreases the uptake of glucose by insulin-sensitive tissues, such as skeletal muscles, and enhances glucose availability for the mammary gland, which is insulin-insensitive (Zhao et al., 1996; Nishimoto et al., 2006; van Knegsel et al., 2007). Therefore, insulin is a very interesting candidate molecule concerning the paradox between yield, metabolic diseases, and reproductive performance.

The factors influencing insulin release in cows remain poorly documented. In humans, prolonged periods of elevated NEFA concentrations, such as obesity, increase the risk of type II diabetes mellitus. This seems to be due to decompensation and exhaustion of the Langerhans islets after prolonged episodes of insulin resistance and hyperinsulinaemia (Golay and Ybarra, 2005). Apart from this, a direct deleterious effect of fatty acids on the pancreatic B-cell insulin secretion and viability has been demonstrated by in vitro studies in man (Zhou and Grill, 1995) and rat (Maedler et al., 2001). Because dairy cows are also exposed to high-NEFA concentrations throughout periods of NEB, we hypothesized that they also suffer from an impaired insulin secretion. The aims of our study were (1) to evaluate glucose-induced plasma insulin responses at several time points in the peripartum period using intravenous glucose tolerance tests (IVGTT), (2) to determine metabolic risk factors associated with low plasma insulin responses, and (3) to relate metabolic factors with the resumption of ovarian cyclicity.

\section{MATERIALS AND METHODS}

\section{Selection of the Animals}

Twenty-seven multiparous dairy cows with a high genetic merit for milk yield, housed at the research dairy farm of Ghent University (Biocentrum Agrivet, Melle,
Belgium), were studied from $14 \mathrm{~d}$ before the expected calving date until $42 \mathrm{~d}$ pp. Cows in the herd were taken up in the Flemish Cattle Breeding Association and had an average 305-d fat-corrected milk yield of 11,500 $\mathrm{kg}$ in the previous lactation and an average genetic index for production of $306.8 \mathrm{~kg}$ above the mean of all cows in the Association. Experiments were approved by the Ethical Committee of the Faculty of Veterinary Medicine, Ghent. Cows were housed in a loose cubicle stable and milked on average $2.68 \pm 0.03$ times per day by an automated milking system (VMS, DeLaval NV, Ghent, Belgium). Whenever a cow had not been milked for more than $10 \mathrm{~h}$, the dairyman was automatically alerted, and the cow was guided to the milking robot.

In the dry period, the ration consisted of wheat straw, offered ad libitum in the bunk and refreshed on a daily basis, approximately $8 \mathrm{~kg} \mathrm{DM}$ of corn silage, and 1.4 $\mathrm{kg}$ DM of soybean meal per day (Aveve, Merksem, Belgium). The dry period ration was supplemented with $25 \mathrm{~g}$ of magnesium oxide (Nutreco, Ghent, Belgium) and $200 \mathrm{~g}$ of a dry period mineral mixture (Nutreco) per day. During the last 7 to $10 \mathrm{~d}$ before the expected calving date, cows were introduced into the herd and offered the lactation roughages and $2 \mathrm{~kg}$ of concentrate per day (Aveve). During lactation, cows were fed ad libitum a mixed ration consisting of approximately $45 \%$ corn silage, $13.5 \%$ grass silage, $20 \%$ sugarbeet pulp, $12 \%$ corncob mix, $8 \%$ soybean meal, and $1.5 \%$ hay on a DM basis. Overall, the TMR contained approximately $1.606 \mathrm{Mcal}$ of $\mathrm{NE}_{\mathrm{L}}$ and $79.6 \mathrm{~g}$ of digestible intestinal protein per kilogram of DM. The different components of the ration were weighed before feeding, and total daily DMI of cows was estimated at $15 \mathrm{~kg}$ of roughage (corn silage, grass silage, sugarbeet pulp, and hay), $2.25 \mathrm{~kg}$ of corncob mix, and $1.5 \mathrm{~kg}$ of soybean meal. Based on an expected daily peak milk yield of $45 \mathrm{~kg}$, cows were given maximally $8 \mathrm{~kg}$ of concentrate per day. This maximum was gradually reached by 50 DIM; later on, it was adapted individually based on differences in actual milk yield, DMI, expected lactation length, and body condition. Two kilograms of concentrate was offered during robot milking; the rest was taken up voluntarily at automated feed dispensers. More information about the composition of the dry period mineral mixture and the different concentrates and roughages is summarized in Table 1 and Table 2.

The health status of the cows was estimated subjectively by observation of individual milk yield, milk composition and concentrate intake, conversation with the herd manager, and regular clinical inspections. Four cows with disorders that severely affected feed intake and milk yield, such as abomasal dislocation followed by surgery and dystocia followed by caesarean section, were excluded from the study, reducing the number of 
Table 1. Composition of the dry period mineral mixture ${ }^{1}$

\begin{tabular}{lc}
\hline Compound & Concentration \\
\hline Vitamins & \\
Vitamin A & $500,000 \mathrm{IU} / \mathrm{kg}$ \\
Vitamin $\mathrm{D}_{3}$ & $100,000 \mathrm{IU} / \mathrm{kg}$ \\
Vitamin E & $8,000 \mathrm{IU} / \mathrm{kg}$ \\
Choline chloride & $5,000 \mathrm{IU} / \mathrm{kg}$ \\
Minerals & \\
Sodium selenite & $12.8 \mathrm{mg} / \mathrm{kg}$ \\
Organic selenite & $7 \mathrm{mg} / \mathrm{kg}$ \\
Calcium & $4 \%$ \\
Phosphorus & $5 \%$ \\
Sodium & $6.2 \%$ \\
Magnesium & $7.5 \%$ \\
\hline
\end{tabular}

${ }^{1}$ Nutreco, Ghent, Belgium.

cows in the study to 23. All data of those 4 cows were omitted from statistical analyses.

\section{IVGTT}

On $14 \mathrm{~d}$ before the expected calving date and on 14 and $42 \mathrm{~d} \mathrm{pp}$, an IVGTT was performed. At these time points, cows were expected to be in positive energy balance, at the nadir of NEB, and recovering from NEB (Jorritsma et al., 2003). Because the gestation length of most cows was slightly longer than expected, the interval between the first IVGTT and actual calving date ranged from 9 to 28 d (mean: $18 \pm 1.32$ d). From $0630 \mathrm{~h}$, the selected cows were automatically separated and restrained after milking. Cows that had not been milked by $0800 \mathrm{~h}$ were guided to the milking robot and separated. All IVGTT were performed around $1000 \mathrm{~h}$, within 2 to $3.5 \mathrm{~h}$ after concentrate intake during milking. A 12-gauge catheter (Intraflon, Vygon, Brussels, Belgium) was inserted in the jugular vein and fixed to the skin. Cows were allowed to rest for $30 \mathrm{~min}$ after insertion of the catheter until blood sampling was started. Stress was avoided as much as possible; cows generally continued to ruminate and appeared relaxed during the test. The body weight was estimated based on the average dry period weight of the herd and the size and condition score of the cow and varied between 520 and $750 \mathrm{~kg}$. Blood samples were obtained from the catheter in evacuated gel-coated and fluorinized blood tubes (Vacutainer, Terumo Europe NV, Leuven, Belgium) on $-10,0,4,8,12,18,25,36,45$, and 60 min relative to the infusion of $150 \mathrm{mg}$ of glucose per kilogram of body weight (aqueous solution of $300 \mathrm{mg} / \mathrm{L}$; glucose dextrose, Eurovet, Heusden-Zolder, Belgium), according to the protocol described by Holtenius et al. (2003). The catheter was rigorously flushed after every infusion or sampling. Blood samples were centrifuged $(2,000 \times \mathrm{g}, 30 \mathrm{~min})$ within $1.5 \mathrm{~h}$ after collection, and serum and plasma were stored at $-25^{\circ} \mathrm{C}$ until analysis for glucose and insulin. As measures for the strength of the insulin response to a glucose load, the area under the curve (AUC; $\mu \mathrm{U} / \mathrm{mL} \cdot \mathrm{min}$ ) of insulin concentration was computed as the total insulin increment above basal levels during the 60 min after infusion, as described by Holtenius et al. (2003). Similarly, AUC of glucose $(\mathrm{mmol} / \mathrm{L} \cdot \mathrm{min})$ was calculated. Clearance rates of insulin $\left(\mu \mathrm{U} / \mathrm{mL} \cdot \mathrm{min}^{-1}\right)$ and glucose $\left(\mathrm{mmol} / \mathrm{L} \cdot \mathrm{min}^{-1}\right)$ were considered linear and were defined by calculating the steepness of the downward slope of concentration in time. Insulin and glucose peak concentrations were determined.

\section{Blood Sampling for Glucose, Insulin, and NEFA}

Blood samples were obtained on $14 \mathrm{~d}$ before the expected calving date (mean interval to true calving date: $18 \pm 1.32 \mathrm{~d}$ ) and on $4,8,12,15,18,21,25,28,32$, 35 , and $39 \mathrm{~d} \mathrm{pp}$. After milking, cows were separated, restrained, and sampled as described above. Agitation of the cows was avoided, because stress may interfere with endocrine and metabolic variables. Also, blood

Table 2. Contents of the different feed components in the ration ${ }^{1}$

\begin{tabular}{lcccc}
\hline & \multicolumn{3}{c}{ Contents } \\
\cline { 2 - 4 } Nutrient & DM, \% & $\begin{array}{c}\text { Fiber/kg } \\
\text { of DM, g }\end{array}$ & $\begin{array}{c}\text { NE } / \text { kg } \\
\text { of DM, Mcal }\end{array}$ & $\begin{array}{c}\mathrm{DIP}^{2} / \mathrm{kg} \\
\text { of DM, g }\end{array}$ \\
\hline Concentrate & 87 & 105 & 1.584 & 115 \\
Soybean meal & 87 & 100 & 1.535 & 200 \\
Corn silage & 30.1 & 190 & 1.520 & 48 \\
Grass silage & 38 & 250 & 1.485 & 68 \\
Beet pulp & 20.9 & 197 & 1.733 & 104 \\
Corncob mix & 61 & 28 & 1.988 & 69 \\
Hay & 83 & 260 & 0.713 & 3 \\
Wheat straw & 84 & 420 & & \\
\hline${ }^{1}$ Concentrate and soybean meal were purchased (AVEVE, Merksem, Belgium). All other nutrients had been \\
produced on the farm.
\end{tabular}


samples were taken before any other manipulations took place (e.g., rectal examination) to avoid stress. The blood sampling was performed by puncture of the coccygeal vein or artery using evacuated gel-coated and fluorinized blood tubes. Blood samples were centrifuged and stored as described before and analyzed for glucose, NEFA, insulin, and progesterone.

\section{Gynecological Examination}

Every third day, cows were subjected to visual inspection, rectal palpation, and transrectal ultrasonographic examination of the genital tract to assess the time of ovulation and uterine involution and to diagnose disorders. Ultrasound examination was performed using a 7.5-MHz linear array probe (Pie Medical, Maastricht, the Netherlands). Ovulation was defined by the disappearance of the dominant follicle followed by the formation of a corpus luteum accompanied by an increase in blood progesterone above $2 \mathrm{ng} / \mathrm{mL}$, as mentioned by Gutierrez et al. (2006). Endometritis was diagnosed by the presence of vaginal discharge with foul odor or color, or both, in combination with an enlarged uterus. Cystic ovarian disease was diagnosed by the presence of a follicular structure of $\geq 2.5 \mathrm{~cm}$ in the absence of a corpus luteum for at least 10 consecutive days, in agreement with the definition of Woolums and Peter (1994).

\section{Analyses}

All analyses were performed semiautomatically at the Clinical Chemistry Laboratory of the University Hospital, Ghent, Belgium. Interassay CV of the analyses were calculated on a large number of control samples integrated daily in the runs over a long period of time; the intraassay CV was computed on a regular basis on a smaller number of control samples within 1 run. Control samples within the physiological and the pathological range were used.

Glucose concentrations ( $\mathrm{mmol} / \mathrm{L})$ were defined by the hexokinase method followed by colorimetric analysis using the Cobas GLUC2 kit (Roche Diagnostics, Indianapolis, IN). The detection limit of this kit was 0.11 $\mathrm{mmol} / \mathrm{L}$. The inter- and intraassay $\mathrm{CV}$ of the analysis were $<1.15$ and $<0.8 \%$, respectively. Concentrations of NEFA (mmol/L) were measured via an enzymatic method followed by colorimetric analysis using the NEFA C Kit (Wako Chemicals, Richmond, VA). The interassay $\mathrm{CV}$ of this kit was $<1.75 \%$. Insulin $(\mu \mathrm{U} / \mathrm{mL})$ and progesterone $(\mathrm{ng} / \mathrm{mL})$ analyses were performed by electrochemiluminescence immunoassay using the Cobas Insulin and Progesterone kits (Roche Diagnos- tics). Detection limits of insulin and progesterone were $0.200 \mu \mathrm{U} / \mathrm{mL}$ and $0.095 \mathrm{ng} / \mathrm{mL}$, respectively. Inter- and intraassay CV were $<3.8 \%$ and $<2 \%$ for insulin and $<5.2 \%$ and $<3 \%$ for progesterone, respectively.

\section{Statistics}

All statistical analyses were performed using SPSS (version 14.0; SPSS Inc., Chicago, IL) or S-PLUS (Version 7.0, Insightful, Seattle, WA). Descriptive statistics are expressed as the mean \pm standard error. Data were tested for normality using the Kolmogorov-Smirnov method and transformed whenever necessary.

IVGTT. The associations between lipolysis and 6 IVGTT outcome variables (AUC, peak concentrations and clearance rates for insulin and glucose, referred to as $\mathrm{AUC}_{\text {ins }}, \mathrm{AUC}_{\text {gluc }}, \mathrm{Peak}_{\text {ins }}, \mathrm{Peak}_{\text {gluc }}, \mathrm{Cl}_{\text {ins }}$, and $\mathrm{Cl}_{\text {gluc }}$, respectively) at different time points relative to calving were studied. However, some adjustments needed to be made first. To correctly evaluate the insulin response to a certain amount of glucose, we decided to calculate the $\mathrm{AUC}_{\text {ins: }}: \mathrm{AUC}_{\text {gluc }}$, and the Peak $\mathrm{ins}_{\text {ins }}: \mathrm{AUC}_{\text {gluc }}$ ratios and to use these corrected terms, $\mathrm{AUC}^{*}{ }_{\text {ins }}$ and Peak ${ }^{*}$ ins, as estimators of insulin response. Furthermore, averages $\left(\mathrm{NEFA}_{\mathrm{av}}\right)$ were computed for the NEFA concentrations from the first analysis until the time of IVGTT to represent more closely the chronic exposure to elevated NEFA concentrations. In the final mixed effect model, cow was considered a random factor, whereas time (categorical: dry period, $14 \mathrm{~d}$ pp and $42 \mathrm{~d} \mathrm{pp}$; repeated measurements) and $\mathrm{NEFA}_{\mathrm{av}}$ (continuous) were fixed factors. Pairwise comparisons between different time categories were made. Linear correlations between $\mathrm{AUC}^{*}{ }_{\text {ins }}$ on $-14,14$, and $42 \mathrm{~d}$ pp were computed. Finally, linear correlations between milk yield and $\mathrm{Cl}_{\text {gluc }}$ were computed on 14 and $42 \mathrm{~d}$ pp.

Glucose, Insulin, and NEFA. Glucose, insulin, and NEFA concentrations during the dry period and on $4 \mathrm{~d}$ pp were compared using a dependent-samples $t$-test. Glucose, insulin, and NEFA concentrations during lactation were investigated over time (repeated measurements) using a mixed effect model. Cow was included as a random factor and time (continuous variable) as a fixed factor. Possible nonlinear associations were studied by including a quadratic term, time ${ }^{2}$, in the different models.

Gynecological Examination. The effects of prepartum and pp lipolysis and $\mathrm{AUC}_{\text {ins }}$ on the time of first ovulation were investigated using nonparametric survival analysis. Ovulation was defined as the event, and day pp was considered as the time factor. Cows that had not ovulated before $42 \mathrm{~d}$ pp were censored. Cows were categorized as in high or low prepartum 
lipolysis $\left(\mathrm{NEFA}_{\text {dry,high }}\right.$ and $\left.\mathrm{NEFA}_{\text {dry,low }}\right)$, in high or low pp lipolysis $\left(\mathrm{NEFA}_{\text {high }}\right.$ and $\left.\mathrm{NEFA}_{\text {low }}\right)$, and with high or low $\mathrm{AUC}^{*}{ }_{\text {ins }}\left(\mathrm{AUC}^{*}\right.$ high and $\mathrm{AUC}^{*}$ low $)$, relative to the median of the 23 cows studied. Kaplan-Meier graphs were generated.

\section{RESULTS}

\section{IVGTT}

Insulin Response. All IVGTT outcome variables were transformed logarithmically (Ln) to obtain better normality of the data. Results of the different IVGTT measurements in time are displayed in Table 3.

Both $\operatorname{Ln}\left(\mathrm{AUC}^{*}{ }_{\text {ins }}\right)$ and $\operatorname{Ln}\left(\mathrm{Peak}^{*}{ }_{\text {ins }}\right)$ were lower on 14 and $42 \mathrm{~d}$ pp compared with the dry period $(P<0.005)$, and $\operatorname{Ln}\left(\mathrm{AUC}^{*}{ }_{\text {ins }}\right)$ was lower on $14 \mathrm{~d}$ compared with $42 \mathrm{~d}$ pp $(P<0.05)$. There was a positive correlation between Ln (AUC* ${ }^{*}$ ) $)$ during the dry period and on $14 \mathrm{~d}$ pp (R $=0.461 ; P<0.05)$ and between $14 \mathrm{~d} p p$ and $42 \mathrm{~d} \mathrm{pp}(\mathrm{R}$ $=0.478 ; P<0.05)$. The factor $\mathrm{NEFA}_{\mathrm{av}}$ was negatively related to $\operatorname{Ln}\left(\mathrm{AUC}^{*}{ }_{\text {ins }}\right)$ and $\operatorname{Ln}\left(\mathrm{Peak}^{*}{ }_{\text {ins }}\right)(P<0.001)$. It was found that $\mathrm{Ln}\left(\mathrm{Cl}_{\text {ins }}\right)$ had a tendency to decrease on 14 and $42 \mathrm{~d}$ pp compared with the dry period $(P=0.051$ and 0.054 , respectively) but was not related to $\mathrm{NEFA}_{\mathrm{av}}$ $(P=0.31)$.

Glucose Response. It was found that $\mathrm{Ln}\left(\mathrm{AUC}_{\mathrm{gluc}}\right)$ was lower and $\mathrm{Ln}\left(\mathrm{Cl}_{\text {gluc }}\right)$ was greater on 14 and $42 \mathrm{~d}$ pp compared with the dry period $(P<0.01)$. It was also found that $\mathrm{Ln}\left(\mathrm{Peak}_{\mathrm{gluc}}\right)$ had a tendency to decrease pp $(P=0.054)$. Glucose AUC, peak concentration, and clearance rate were not related to $\mathrm{NEFA}_{\text {av }}(P=0.48, P$ $=0.15$, and $P=0.13$, respectively). Milk yield tended to be positively related to $\mathrm{Ln}\left(\mathrm{AUC}_{\text {gluc }}\right)(\mathrm{R}=0.252 ; P=$ 0.072).

\section{Milk Yield, Glucose, Insulin, and NEFA}

For all of the pp glucose, insulin, and NEFA analyses, the quadratic term for time was not significant; hence, it was omitted from the different models. The evolution of the different concentrations over time was therefore considered to be linear.

Milk Yield Average daily milk yields (L) during the first to the seventh week of lactation were $29.17 \pm 1.26$, $40.11 \pm 1.16,43.06 \pm 1.18,44.96 \pm 1.44,46.11 \pm 1.40$, $46.09 \pm 1.30$, and $46.07 \pm 1.48$, respectively.

Glucose. Glucose concentrations were normally distributed. Glucose concentrations were lower on $4 \mathrm{~d}$ pp compared with dry-off $(P<0.001)$. During lactation, glucose concentrations increased over time $(P<0.001$, Figure 1).

Insulin. Insulin concentrations were not normally distributed and underwent square root transformation. Transformed insulin concentrations, $\sqrt{ }(\mathrm{Ins})$, were lower on $4 \mathrm{~d}$ pp compared with the moment of drying-off $(P<$ $0.001)$. Insulin concentrations increased over time during lactation $(P<0.001$, Figure 2$)$.

NEFA. Nonesterified fatty acid concentrations were not normally distributed and underwent logarithmic transformation. Transformed NEFA concentrations, Ln (NEFA), were greater $(P<0.001)$ at the onset of lactation compared with dry-off. During lactation, NEFA concentrations decreased over time $(P<0.001$, Figure 3).

\section{Gynecological Examination}

Fourteen out of 23 cows (60.9\%) ovulated within 42 $\mathrm{d}$ pp. Within the ovulating cows, the mean interval from parturition to first ovulation was $22.21 \pm 1.80 \mathrm{~d}$.

Table 3. Different measurements of the intravenous glucose tolerance tests on different time points relative to calving ${ }^{1}$

\begin{tabular}{|c|c|c|c|c|}
\hline Item $^{2}$ & \multicolumn{3}{|c|}{ Days relative to calving } & Overall $P$-value ${ }^{3}$ \\
\hline \multicolumn{5}{|l|}{ Insulin response } \\
\hline $\mathrm{Ln}\left(\mathrm{AUC}^{*}{ }_{\mathrm{ins}}\right), \mu \mathrm{U} / \mathrm{mL} \cdot \min$ & $2.09 \pm 0.11^{\mathrm{a}}$ & $1.14 \pm 0.12^{\mathrm{b}}$ & $1.37 \pm 0.12^{\mathrm{c}}$ & $P<0.0001$ \\
\hline $\operatorname{Ln}\left(\operatorname{Peak}^{*}{ }_{\text {ins }}\right), \mu \mathrm{U} / \mathrm{mL}$ & $-1.20 \pm 0.12^{\mathrm{a}}$ & $-1.71 \pm 0.10^{\mathrm{b}}$ & $-1.71 \pm 0.10^{\mathrm{b}}$ & $P<0.0001$ \\
\hline $\begin{array}{l}\mathrm{Ln}\left(\mathrm{Cl}_{\text {ins }}\right), \mu \mathrm{U} / \mathrm{mL} \cdot \mathrm{min}^{-1} \\
\text { Glucose response }\end{array}$ & $-1.35 \pm 0.13$ & $-1.60 \pm 0.10$ & $-1.61 \pm 0.12$ & $P=0.081$ \\
\hline $\mathrm{Ln}\left(\mathrm{Peak}_{\mathrm{gluc}}\right), \mathrm{mmol} / \mathrm{L}$ & $0.31 \pm 0.02$ & $0.23 \pm 0.02$ & $0.27 \pm 0.03$ & $P=0.054$ \\
\hline $\mathrm{Ln}\left(\mathrm{Cl}_{\text {gluc }}\right), \mathrm{mmol} / \mathrm{L} \cdot \mathrm{min}^{-1}$ & $-4.16 \pm 0.07^{\mathrm{a}}$ & $-3.91 \pm 0.03^{b}$ & $-3.90 \pm 0.04^{\mathrm{b}}$ & $P<0.0001$ \\
\hline
\end{tabular}

\footnotetext{
${ }^{\mathrm{a}-\mathrm{c}}$ Means within a row with different superscripts differ $(P<0.05)$.

${ }^{1}$ Data are presented as mean \pm standard error.

${ }^{2} \mathrm{AUC}^{*}{ }_{\text {ins }}=$ area under the curve of insulin concentration in time, corrected for glucose area under the curve; Peak ${ }^{*}{ }_{\text {ins }}=$ peak concentration of insulin, corrected for $\mathrm{AUC}_{\text {gluc }} ; \mathrm{Cl}_{\text {ins }}=$ clearance rate of insulin; $\mathrm{AUC}_{\text {gluc }}=$ area under the curve of glucose concentration in time; Peak ${ }_{\text {gluc }}=$ peak concentration of glucose; $\mathrm{Cl}_{\text {gluc }}=$ clearance rate of glucose.

${ }^{3}$ The $P$-value of the overall effect of time on all items is included.
} 


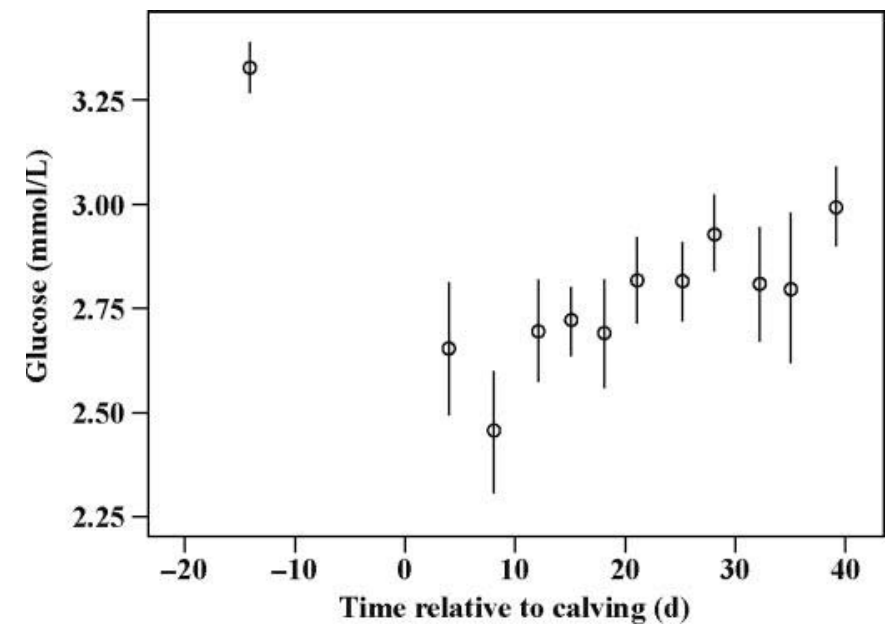

Figure 1. Glucose concentrations at different time points relative to calving. Results are displayed as mean \pm standard error.

The remaining 9 cows suffered from DFO, and COD was diagnosed in 3 of them. Three cows suffered from endometritis; however, 2 of these cows managed to ovulate before $42 \mathrm{~d} \mathrm{pp}$. According to the survival graph (Figure 4), cows in mild lipolysis during the dry period $\left(\mathrm{NEFA}_{\text {dry,low }}\right)$ had a tendency to ovulate earlier in lactation and reach a greater proportion of ovulation by 42 $\mathrm{d}$ compared with cows in greater prepartum lipolysis (NEFA $\mathrm{N}_{\text {dry,high }} ; P=0.080$ ). The NEFA concentrations during the lactation and $\mathrm{AUC}^{*}$ ins were not related with the onset of ovulation in this study (data not shown).

\section{DISCUSSION}

The central aim of our study was to evaluate the insulin response to a glucose load at different time points relative to calving. The nadir concentrations of glucose and insulin occurred on 8 and $12 \mathrm{~d} p \mathrm{pp}$, respectively, whereas NEFA peaked at $4 \mathrm{~d}$ pp. These data suggest that the nadir of NEB in these cows was situated on average between 4 and $12 \mathrm{~d} p \mathrm{p}$, which is in agreement with the 2.5 to $12 \mathrm{~d}$ range reported by Jorritsma et al. (2003). We estimate that the time point of $14 \mathrm{~d}$ pp was well chosen to perform the IVGTT.

Insulin is a peptide hormone that is synthesized and secreted by pancreatic B-cells in response to propionate, butyrate, and glucose (Mashek et al., 2001) and metabolized by the liver and the kidneys (Valera Mora et al., 2003). It needs to be stressed that the insulin AUC, peak concentrations, and clearance rates are the result of a dynamic relation between secretion and excretion and the simultaneous secretion of other gastrointestinal hormones, as stated by Golay and Ybarra (2005). Therefore, secretion and excretion cannot be regarded as 2 different and isolated processes. However,

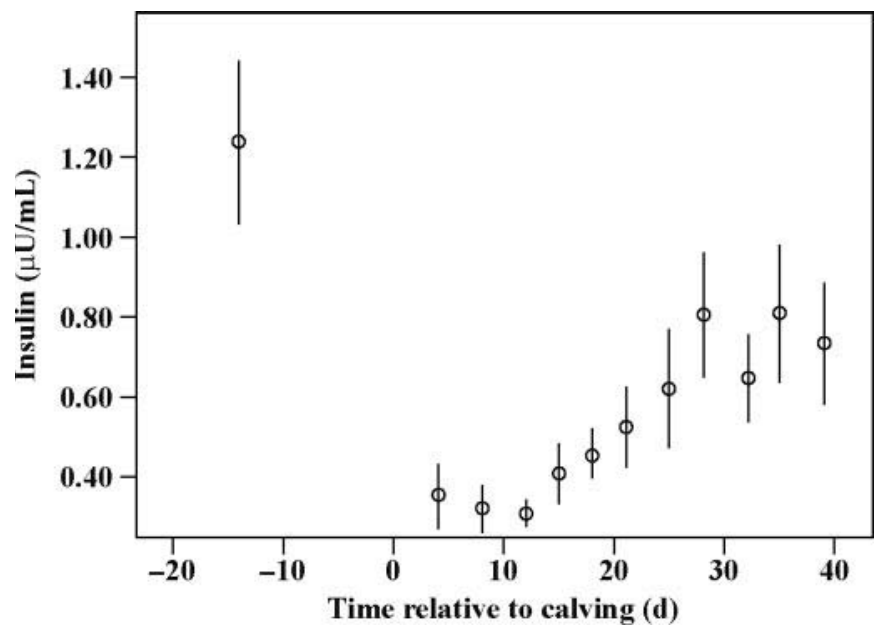

Figure 2. Insulin concentrations at different time points relative to calving. Results are displayed as mean \pm standard error.

by interpreting all IVGTT measurements collectively, some assumptions can be made about which process is stimulated or inhibited.

Insulin AUC and peak concentrations were corrected for the concurrent glucose AUC to avoid the possibility that fluctuations in the estimated body weight, and hence, the administered glucose dose, would interfere with the insulin response. Both corrected terms, AUC ${ }^{*}$ ins and Peak ${ }^{*}$ ins, were lower pp compared with the dry period. These findings correspond to the conclusions drawn by Holtenius et al. (2003). Several (steroid) hormones, such as progesterone, have greater clearance rates during lactation due to the increased metabolic activity of the liver (Sangsritavong et al., 2002). However, in our study, insulin clearance rates had a tendency to decrease during the pp period. Hence, the lower insulin AUC seems to be solely due to a lower insulin secretion and not to an increased insulin clearance rate. There was a large diversity among cows regarding the insulin outcome variables. A positive correlation was found between insulin AUC during the dry period and on $14 \mathrm{~d} p$ p and between 14 and $42 \mathrm{~d}$ pp. In other words, cows that responded poorly to a glucose load in the dry period seemed to do so during lactation as well. As stated by Jorritsma et al. (2003), persistent low insulin levels during NEB may be indicative for poor adaptation of the cow to increased energy needs, with an increased risk for reproductive and metabolic disturbances.

Low peripheral insulin concentrations induce a glucose-sparing status and enhance glucose availability for the mammary gland (van Knegsel et al., 2007). Insulin concentrations after parturition have been reported to have a moderate heritability (Swali and Wathes, 2006), and it has been suggested that 


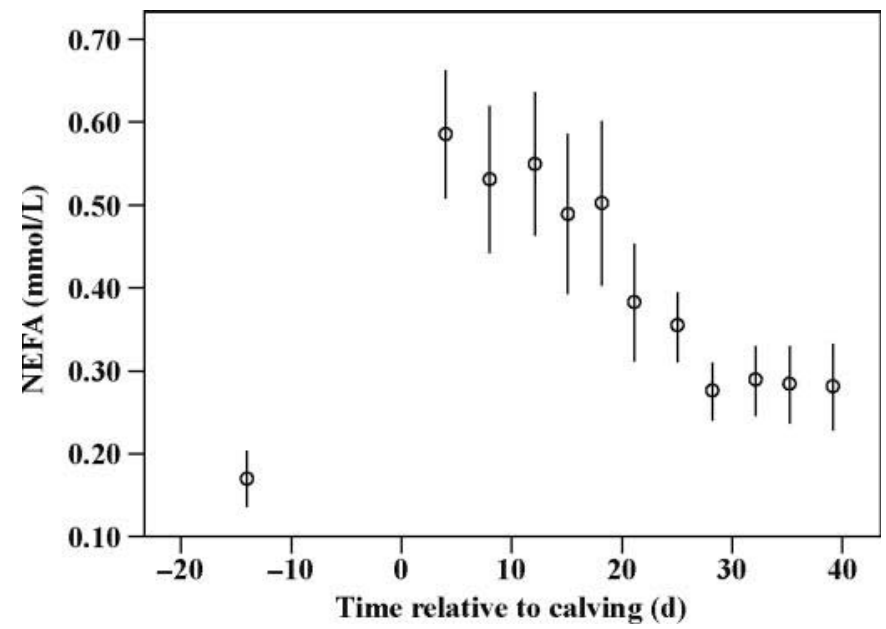

Figure 3. Nonesterified fatty acid concentrations at different time points relative to calving. Results are displayed as mean \pm standard error.

high-yielding dairy cows may have a genetic tendency to lower insulin levels (Veerkamp et al., 2003; Gutierrez et al., 2006). Indeed, very recently, Hammon et al. (2007) observed a lower glucose-dependent insulin response in heifers selected for milk production compared with beef heifers. Interestingly, this difference was only apparent during lactation and not during the dry period. Taken together, there are suggestions in the literature that the insulin response to glucose may be defined by both genetic and metabolic factors. Our current findings support this hypothesis: NEFA concentrations were negatively correlated to insulin AUC and peak concentrations, suggesting that elevated NEFA concentrations during lactation may interfere with glucose-induced insulin secretion. Other studies have pointed out that NEFA have a detrimental effect on several bovine cell types, including granulosa cells (Vanholder et al., 2004), oocytes (Leroy et al., 2005), and liver cells (Roche, 2006), but also on human and rat pancreatic B-cells. In man, NEFA are suggested to play a crucial role in the development of pancreatic insufficiency in type II diabetes (Mason et al., 1999). Additionally, Bobe et al. (2004) mentioned pancreatic involution as a complication of fatty liver syndrome in dairy cows. In our study, however, only a correlation but no causal relationship between NEFA and insulin response has been demonstrated, and an equally plausible explanation would be that low-insulin concentrations stimulate lipolysis and elevate NEFA levels. To elucidate the exact mechanism of the lower insulin response in cows, further in vitro studies are required.

Glucose AUC was highest in the prepartum period and decreased on 14 and $42 \mathrm{~d}$ pp. Glucose clearance rates were greater on 14 and $42 \mathrm{~d}$ pp compared with

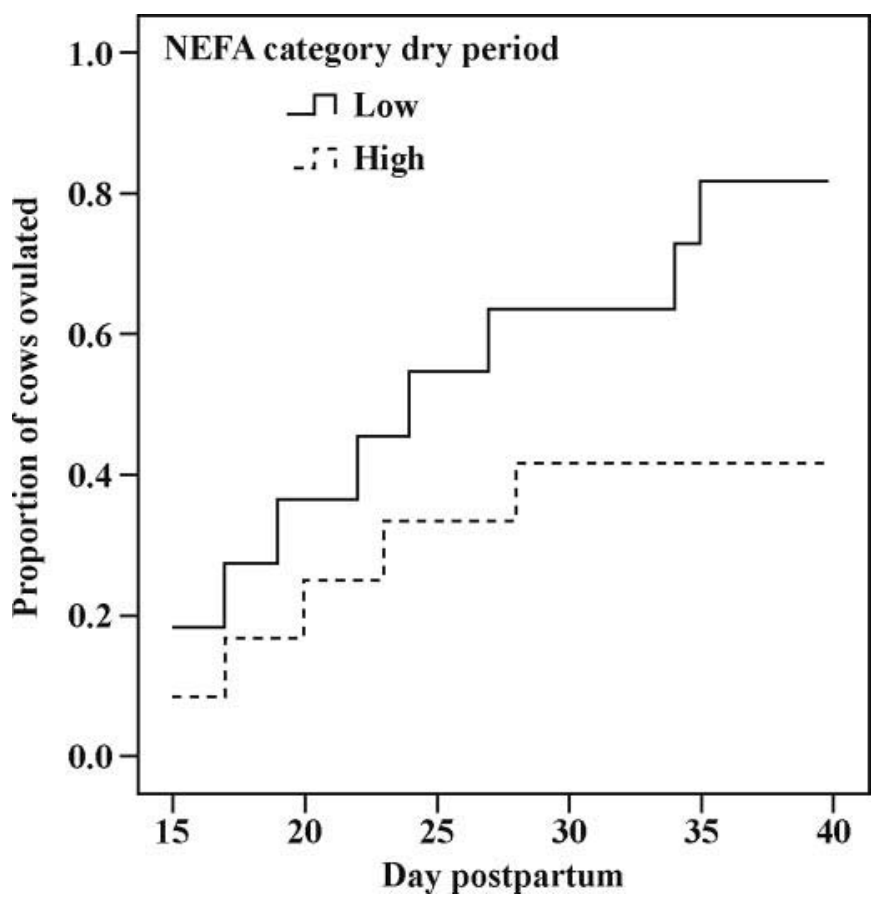

Figure 4. Cumulative survival chart. Proportion of cows that have ovulated over time in the groups of cows with a low $\left(\mathrm{NEFA}_{\text {dry, low }}\right)$ and a high rate of lipolysis $\left(\mathrm{NEFA}_{\text {dry high }}\right)$ during the dry period, expressed by their respective NEFA levels prepartum. The NEFA dry,low cows tended to reach a greater proportion of ovulation after $42 \mathrm{~d}$ compared with $\mathrm{NEFA}_{\text {dry,high }}$ cows $(P=0.080)$.

the dry period. Several authors consider peripheral insulin resistance, caused by excessive NEFA and growth hormone concentrations, as a crucial risk factor for metabolic and reproductive diseases during the transition period (Herzog, 2001; Oikawa and Oetzel, 2006; Pires et al., 2007). Intracellular glucose uptake occurs by facilitated transport via glucose transporter molecules (GLUT) incorporated into the cellular membrane. There are 7 different types of GLUT, which are all expressed under different biological stimuli. Skeletal muscles and adipose tissue contain only GLUT 4, the expression of which is strictly insulin-dependent, whereas udder and liver tissue contain predominantly GLUT 1 and 3, expressed independently of insulin (Zhao et al., 1996; Nishimoto et al., 2006). The glucose clearance rate reflects both the insulin-dependent and the insulin-independent glucose consumption. Because insulin concentrations and insulin sensitivity of the peripheral tissues are reported to decrease during NEB (Bell and Bauman, 1997; Holtenius et al., 2003), the greater rate of glucose clearance found in our study is likely to be explained by greater insulin-independent glucose consumption, mainly representing glucose uptake by the mammary gland during lactation. The fact that glucose clearance rates tended to be positively re- 
lated to milk yield supports this statement. Therefore, based on the IVGTT results only, no conclusions can be drawn concerning peripheral insulin sensitivity.

In the present study, $39.1 \%$ of the cows did not ovulate before $42 \mathrm{~d} \mathrm{pp}$. This is markedly greater than the $21.5 \%$ DFO reported by Opsomer et al. (2000) and the $13.2 \%$ observed by Shrestha et al. (2004a). Resumption of cyclicity tended to occur earlier pp in cows with lower NEFA levels during the dry period $\left(\mathrm{NEFA}_{\text {dry,low }}\right.$ group). This can be seen in the context of the findings by Kokkonen et al. (2005), who have demonstrated that cows mobilizing more adipose tissue before calving continued to suffer from a more severe NEB during the first weeks of lactation. As stated before, length and severity of the NEB affect the time of first ovulation. The relevance of a single NEFA measurement during the dry period has been demonstrated before by LeBlanc et al. (2005), who stated that the risk for abomasal dislocation is significantly greater in cows mobilizing more fatty acids prepartum. In our study, statistical significance was not reached, and the number of cows was small; a study on a larger number of cows might shed more light on the use of prepartum NEFA measurements as a tool for prediction of fertility pp. In contrast, NEFA concentrations during lactation did not affect the time of ovulation. This may have been due to the small number of cows and to considerable fluctuation of NEFA both between and within cows. It was found that $\mathrm{AUC}^{*}$ ins did not seem to have any effect on the time of first ovulation. In vitro cultured granulosa cells respond to insulin by estrogen synthesis and proliferation in a dose-dependent manner (Gutierrez et al., 1997). However, besides absolute insulin concentrations, ovarian sensitivity to insulin also needs to be taken into account, because insulin and IGF-1 receptors on granulosa cells undergo considerable changes as the follicle develops (Spicer and Echternkamp, 1995). Further research on granulosa cell insulin sensitivity under different metabolic circumstances is required to fully understand the interactions between insulin and the ovarian function.

\section{CONCLUSIONS}

Our study demonstrates a decrease of the glucoseinduced insulin AUC and peak concentrations during lactation compared with the dry period. These findings, taken together with the fact that the insulin clearance rate did not increase during lactation, suggest that the low AUC is likely to be caused by low insulin secretion. This may present an additional metabolic challenge that the cow has to face during the delicate period of adaptation to lactation. Insulin AUC and peak concentrations were negatively related to concurrent NEFA concentrations. These findings should support further research about the potential negative effects of elevated plasma NEFA concentrations on bovine pancreas cells, as reported in other species.

We have found a high incidence of ovarian dysfunctions in the early pp period. Survival analysis suggested that cows mobilizing less NEFA during the dry period had a tendency to have earlier resumption of ovarian activity. This tendency deserves further investigation in a larger number of cows.

\section{ACKNOWLEDGMENTS}

This research was funded by the Special Research Fund, Ghent University, Grant 01D29105. We appreciate the constructive remarks on the manuscript made by Jos Noordhuizen (Ghent University, Belgium, and National Veterinary School of Lyon, France).

\section{REFERENCES}

Bell, A. W., and D. E. Bauman. 1997. Adaptations of glucose metabolism during pregnancy and lactation. J. Mammary Gland Biol. Neoplasia 2:265-278.

Bobe, G., J. W. Young, and D. C. Beitz. 2004. Invited review: Pathology, etiology, prevention, and treatment of fatty liver in dairy cows. J. Dairy Sci. 87:3105-3124.

Golay, A., and J. Ybarra. 2005. Link between obesity and type 2 diabetes. Best Pract. Res. Clin. Endocrinol. Metab. 19:649-663.

Gong, J. G., W. J. Lee, P. C. Garnsworthy, and R. Webb. 2002. Effect of dietary-induced increases in circulating insulin concentrations during the early postpartum period on reproductive function in dairy cows. Reproduction 123:419-427.

Gutierrez, C. G., B. K. Campbell, and R. Webb. 1997. Development of a long-term bovine granulosa cell culture system: Induction and maintenance of estradiol production, response to folliclestimulating hormone, and morphological characteristics. Biol. Reprod. 56:608-616.

Gutierrez, C. G., J. G. Gong, T. A. Bramley, and R. Webb. 2006. Selection on predicted breeding value for milk production delays ovulation independently of changes in follicular development, milk production and body weight. Anim. Reprod. Sci. 95:193205.

Hammon, H. M., O. Bellmann, J. Voigt, F. Schneider, and C. Kühn. 2007. Glucose-dependent insulin response and milk production in heifers within a segregating resource family population. J. Dairy Sci. 90:3247-3254.

Herzog, K. 2001. Versuche zur pankreatischen Insulin-Response von trockenstehenden und laktierenden Kühen sowie Kühen mit Leberverfettung mittels intravenösem Glucose-toleranztest und hyperglykämischer Clamp-Technik. Inaugural-Dissertation zur Erlangung des Grades einer Doktorin der Veterinärmedizin (Dr. Med. Vet.) durch die Tierärztliche Hochschule Hannover, Germany.

Holtenius, K., S. Agenäs, C. Delavaud, and Y. Chilliard. 2003. Effects of feeding intensity during the dry period. 2. Metabolic and hormonal responses. J. Dairy Sci. 86:883-891.

Ingvartsen, K. L., and N. C. Friggens. 2005. To what extent do variabilities in hormones, metabolites and energy intake explain variability in milk yield? Domest. Anim. Endocrinol. 29:294304.

Jorritsma, R., T. Wensing, T. A. M. Kruip, P. L. A. M. Vos, and J. P. T. M. Noordhuizen. 2003. Metabolic changes in early lactation and impaired reproductive performance in dairy cows. Vet. Res. $34: 11-26$. 
Kokkonen, T., J. Taponen, T. Anttila, L. Syrjälä-Qvist, C. Delavaud, Y. Chilliard, M. Tuori, and A. T. Tesfa. 2005. Effect of body fatness and glucogenic supplement on lipid and protein mobilization and plasma leptin in dairy cows. J. Dairy Sci. 88:1127-1141.

LeBlanc, S. J., K. E. Leslie, and T. F. Duffield. 2005. Metabolic predictors of displaced abomasum in dairy cattle. J. Dairy Sci. 88:159-170.

Leroy, J. L. M. R., T. Vanholder, B. Mateusen, A. Christophe, G. Opsomer, A. de Kruif, G. Genicot, and A. Van Soom. 2005. Nonesterified fatty acids in follicular fluid of dairy cows and their effect on developmental capacity of bovine oocytes in vitro. Reproduction 130:485-495.

Lucy, M. C. 2001. Reproductive loss in high-producing dairy cattle: Where will it end? J. Dairy Sci. 84:1277-1293.

Maedler, K., G. A. Spinas, D. Dyntar, W. Moritz, N. Kaiser, and M. Y. Donath. 2001. Distinct effects of saturated and monounsaturated fatty acids on B-cell turnover and function. Diabetes 50:69-76.

Mashek, D. G., K. L. Ingvartsen, J. B. Andersen, M. Vestergaard, and T. Larsen. 2001. Effects of a four-day hyperinsulinemiceuglycemic clamp in early and mid-lactation dairy cows on plasma concentrations of metabolites, hormones, and binding proteins. Domest. Anim. Endocrinol. 21:169-185.

Mason, T. M., T. Goh, V. Tchipashvili, H. Sandhu, N. Gupta, G. F. Lewis, and A. Giacca. 1999. Prolonged elevation of plasma free fatty acids desensitizes the insulin secretory response to glucose in vivo in rats. Diabetes 48:524-530.

Miyoshi, S., J. L. Pate, and D. L. Palmquist. 2001. Effects of propylene glycol drenching on energy balance, plasma glucose, plasma insulin, ovarian function and conception in dairy cows. Anim. Reprod. Sci. 68:29-43.

Nishimoto, H., R. Matsutani, S. Yamamoto, T. Takahashi, K. G. Hayashi, A. Miyamoto, S. Hamano, and M. Tetsuka. 2006. Gene expression of glucose transporter (GLUT) 1,3 and 4 in bovine follicle and corpus luteum. J. Endocrinol. 188:111-119.

Oikawa, S., and G. R. Oetzel. 2006. Decreased insulin response in dairy cows following a four-day fast to induce hepatic lipidosis. J. Dairy Sci. 89:2999-3005.

Opsomer, G., Y. T. Gröhn, J. Hertl, M. Coryn, H. Deluyker, and A. de Kruif. 2000. Risk factors for post partum ovarian dysfunction in dairy cows in Belgium: A field study. Theriogenology 53:841857.

Pires, J. A. A., A. H. Souza, and R. R. Grummer. 2007. Induction of hyperlipidemia by intravenous infusion of tallow emulsion causes insulin resistance in Holstein cows. J. Dairy Sci. 90:2735-2744.

Roche, J. F. 2006. The effect of nutritional management of the dairy cow on reproductive efficiency. Anim. Reprod. Sci. 96:282-296.

Sangsritavong, S., S. R. Combs, R. Sartori, L. E. Armentano, and M. C. Wiltbank. 2002. High feed intake increases liver blood flow and metabolism of progesterone and estradiol-17b in dairy cattle. J. Dairy Sci. 85:2831-2842.

Shrestha, H. K., T. Nakao, T. Higaki, T. Suzuki, and M. Akita. 2004a. Resumption of postpartum ovarian cyclicity in high-producing Holstein cows. Theriogenology 61:637-649.

Shrestha, H. K., T. Nakao, T. Suzuki, T. Higaki, and M. Akita. 2004b. Effects of abnormal ovarian cycles during pre-service period postpartum on subsequent reproductive performance of high-producing Holstein cows. Theriogenology 61:1559-1571.

Spicer, L. J., and S. E. Echternkamp. 1995. The ovarian insulin and insulin-like growth factor system with an emphasis on domestic animals. Domest. Anim. Endocrinol. 12:223-245.

Swali, A., and D. C. Wathes. 2006. Influence of the dam and sire on size at birth and subsequent growth, milk production and fertility in dairy heifers. Theriogenology 66:1173-1184

Valera Mora, M. E., A. Scarfone, M. Calvani, A. V. Greco, and G. Mingrone. 2003. Insulin clearance in obesity. J. Am. Coll. Nutr. 22:487-493.

Vanholder, T., J. Leroy, J. Dewulf, L. Duchateau, M. Coryn, A. de Kruif, and G. Opsomer. 2005. Hormonal and metabolic profiles of high-yielding dairy cows prior to ovarian cyst formation or first ovulation post partum. Reprod. Domest. Anim. 40:460-467.

Vanholder, T., J. L. M. R. Leroy, A. Van Soom, G. Opsomer, D. Maes, M. Coryn, and A. de Kruif. 2004. Effect of non-esterified fatty acids on bovine granulosa cell steroidogenesis and proliferation in vitro. Anim. Reprod. Sci. 87:33-44.

van Knegsel, A. T. M., H. van den Brand, E. A. M. Graat, J. Dijkstra, R. Jorritsma, E. Decuypere, S. Tamminga, and B. Kemp. 2007. Dietary energy source in dairy cows in early lactation: Metabolites and metabolic hormones. J. Dairy Sci. 90:1477-1485.

Veerkamp, R. F., B. Beerda, and T. van der Lende. 2003. Effects of genetic selection for milk yield on energy balance, levels of hormones, and metabolites in lactating cattle, and possible links to reduced fertility. Livest. Prod. Sci. 83:257-275.

Walsh, R. B., D. F. Kelton, T. F. Duffield, K. E. Leslie, J. S. Walton, and S. J. LeBlanc. 2007. Prevalence and risk factors for postpartum anovulatory condition in dairy cows. J. Dairy Sci. 90:315-324.

Woolums, A. R., and A. T. Peter. 1994. Cystic ovarian condition in cattle. Part I. Folliculogenesis and ovulation. Compend. Contin. Educ. Vet. Pract. 16:935-942.

Zhao, F. Q., W. T. Dixon, and J. J. Kennelly. 1996. Localization and gene expression of glucose transporters in bovine mammary gland. Comp. Biochem. Physiol. 115:127-134.

Zhou, Y. P., and V. Grill. 1995. Long term exposure to fatty acids and ketones inhibits B-cell functions in human pancreatic islets of Langerhans. J. Clin. Endocrinol. Metab. 80:1584-1590. 